\title{
Cervical Fibroepithelial Polyp
}

National Cancer Institute

\section{Source}

National Cancer Institute. Cervical Fibroepithelial Polyp. NCI Thesaurus. Code C40200.

A usually solitary polypoid lesion that arises from the cervix. It usually affects women in their reproductive years. It is characterized by the presence of a connective tissue core and overlying epithelium. 